\title{
The influence of cofactors on allergic reactions to food
}

\author{
Astrid Versluis ${ }^{1}$, Harmieke Van Os-Medendorp ${ }^{1 *}$, Astrid Kruizinga ${ }^{2}$, Anouska Michelsen ${ }^{1}$, Marty Blom², \\ Geert Houben², André Knulst ${ }^{1}$ \\ From Food Allergy and Anaphylaxis Meeting 2014 \\ Dublin, Ireland. 9-11 October 2014
}

\section{Background}

Cofactors, like exercise, alcohol consumption and use of several types of medication, may influence the occurrence and severity of allergic reactions to food. However there is limited evidence on how often cofactors play a role and what their influence is on allergic reactions.

\section{Objective}

To get insight in the influence of cofactors on allergic reactions to food.

\section{Methods}

A baseline questionnaire was completed by every adult patient ( $\geq 18$ years) visiting the outpatients department Allergology for the first time. Patients with food allergy documented by typical allergic symptoms to food and a positive skinpricktest, ImmunoCAP or food challenge were included. Outcome measures were the reported suspected influence of the co-factors exercise, alcohol and medication on allergic complaints to food.

\section{Results}

502 patients were included between 2003-2011. Most patients had allergy to several types of food (mean: 4 different foods). Most common food allergies were fruit and vegetables (73\%), nuts (57\%) and peanuts (38\%). Prevalence of other atopic diseases were asthma 64\%, hay fever $61 \%$ and atopic dermatitis $75 \%$. Of all patients, $5 \%$ used antacids and 2\% used NSAIDs. Beta blockers, angiotensin-receptor inhibitors, ACE inhibitors, protonpomp inhibitors and H2-receptor antagonists were used by $\leq 0.6 \%$ of the patients. Only $13 \%$ of all patients indicated to experience influence of one of the cofactors on

University Medical Centre Utrecht, Utrecht, The Netherlands

Full list of author information is available at the end of the article the severity of allergic complaints; exercise was reported by $9 \%$, alcohol consumption by $5 \%$ and use of analgetics by $0.6 \%$.

\section{Conclusion}

Only a small percentage of patients used medication that might influence the occurrence and severity of allergic reactions to food. Exercise and alcohol were the most frequently reported cofactors but only in less than $10 \%$ of the patients. The importance of these cofactors on severity and eliciting dose for individual patients remains to be elucidated, but at the population level, the influence of these cofactors on threshold distributions is likely to be small.

\section{Authors' details}

${ }^{1}$ University Medical Centre Utrecht, Utrecht, The Netherlands. ${ }^{2}$ TNO, Zeist, The Netherlands.

Published: 30 March 2015

doi:10.1186/2045-7022-5-S3-P51

Cite this article as: Versluis et al:: The influence of cofactors on allergic reactions to food. Clinical and Translational Allergy 2015 5(Suppl 3):P51.

Submit your next manuscript to BioMed Central and take full advantage of:

- Convenient online submission

- Thorough peer review

- No space constraints or color figure charges

- Immediate publication on acceptance

- Inclusion in PubMed, CAS, Scopus and Google Scholar

- Research which is freely available for redistribution

Submit your manuscript at www.biomedcentral.com/submit
() Biomed Central 